\title{
Role of the Target in Synapse Elimination: Studies in Cerebellum of Developing Lurcher Mutants and Adult Chimeric Mice
}

\author{
Sylvia A. Rabacchi, ${ }^{1, a}$ Yannick Bailly, ${ }^{1}$ Nicole Delhaye-Bouchaud, ${ }^{1}$ Karl Herrup, ${ }^{2}$ and Jean Mariani ${ }^{1}$ \\ 'Laboratoire de Neurobiologie du Développement et Institut des Neurosciences (URA 1488), CNRS et Université P. et M. \\ Curie, 75005 Paris, France and ${ }^{2}$ Division of Developmental Neurobiology, E. K. Shriver Center, Waltham, \\ Massachusetts 02254
}

As the mature nervous system is sculpted out of its embryonic anlage, regressive events are a surprisingly common feature. As one example, the establishment of adult innervation in the CNS and PNS often involves a massive withdrawal of previously formed functional synapses. In the cerebellum, the one-to-one relationship of inferior olivary climbing fibers to Purkinje cells is preceded by a transient stage in which each Purkinje cell is multiply innervated. The regulation of this regressive event is still not fully understood; previous studies suggested that some stimulus from the maturing granule cells is necessary. We have used the lurcher $(L c)$ mutation as a model system in which to study this phenomenon. In lurcher mice, Purkinje cells degenerate during the first few postnatal weeks, after receiving synaptic contacts from both inferior olivary neurons and granule cells. We have recorded the climbing fiber responses both in lurcher mutants at postnatal days 14-20 (P14-P20) and in adult lurcher chimeras. In the latter, experimental genetics are used to create a situation in which untreated wild-type Purkinje cells are present in an environment that ranges from $100 \%$ wild-type to nearly mutant. We found that in P14-P16 lurcher mutants, most of the cells recorded $(75 \%)$ remained polyinnervated, whereas in wild-type control mice, only $10 \%$ of the Purkinje cells retained their multiple innervation. By P18-20, it was difficult to find Purkinje cells in the lurcher mutants that would withstand an intracellular electrode. Nonetheless, in those cells that were successfully impaled, most remained multiply innervated. By this age in wild-type mice, $100 \%$ of the Purkinje cells are monoinnervated. Lurcher chimeras were studied in order to determine whether the maintenance of multiple innervation in the mutant is caused by the failure of an external signal or an intrinsic deficiency in the $+/ L c$ Purkinje cells. In the chimeras, all surviving $(+/+)$

\footnotetext{
Received Nov. 11, 1991; revised Apr. 24, 1992; accepted June 23, 1992.

We extend grateful thanks to Dr. Hadi Shojaeian-Zanjani for his critical reading and other help in the preparation of the manuscript. Also, thanks to Monique Millot for her excellent photographic assistance and to Florence Frederic for help with the statistical analyses. This work was supported by INSERM (CRE N.890005), Fondation de la Recherche Medicale, Fondation de France, March of Dimes Birth Defects Foundation (1-1175), and the NIH (NS 20591). Travel grants to support this study were provided by NATO (0540/88) and INSERM ("Projet de collaboration Franco-Americaine"). S.S.R. thanks the Fyssen, Ipsen, Philippe Foundations and the Fidia France for providing postdoctoral financial support.

Correspondence should be addressed to Dr. Karl Herrup, Alzheimer Research Laboratory, Case Western Reserve Medical School, 2116 Abington Road, Cleveland, $\mathrm{OH} 44106$.

${ }^{2}$ Present address: Scuola Normalc Supcriorc, Piazza dei Cavalicri, Pisa, Italy 56126.

Copyright $(1992$ Society for Neuroscience $0270-6474 / 92 / 124712-09 \$ 05.00 / 0$
}

Purkinje cells from which we recorded were innervated by a single climbing fiber. From these results, we advance the hypothesis that in the lurcher mutant the retention of multiple innervation is due to an intrinsic incompetence of the Purkinje cell itself to respond to the granule cell input.

There is now substantial evidence that regressive events are an important part of the normal development of the nervous system. Their role seems to be to sculpt the highly specific connections characteristic of the adult nervous system from the cruder projection patterns of the embryo. Numerous examples of transient axonal exuberance followed by massive withdrawal of collaterals have been described in the last decades (see Cowan et al., 1984); in only a few cases, however, has elimination of functional synaptic contacts made by these exuberant axons been directly demonstrated (see review in Purves and Lichtman, 1977, 1980; Innocenti, 1981; Mariani and Delhaye-Bouchaud, 1987).

In the neuromuscular junction (Redfern, 1970), in autonomic ganglia (I ichtman, 1977; I ichtman and Purves, 1980; Johnson and Purves, 1981), as well as in the avian auditory system (Jackson and Parks, 1982), the initial polyneuronal innervation of a target cell evolves during development such that the adult configuration of one (or only a few) afferent per target is established. An additional example is found in the mammalian cerebellum. During normal development, there is a transient multiple innervation of each Purkinje cell by three to five climbing fiber axons (originating from the inferior olivary neurons). During the second postnatal week, the olivocerebellar projection undergoes a period of regression in which climbing fiber-Purkinje cell contacts are eliminated (Delhaye-Bouchaud et al., 1975; Crepel et al., 1976b, 1981; Mariani and Changeux, 1981a,b). This regressive process leads to a situation of monoinnervation, typical of adulthood, in which each Purkinje cell receives input from only one olivary afferent fiber.

A crucial but still unanswered question is what causes the disappearance of these redundant functional synapses. Data obtained from abnormal cerebella have produced strong evidence for an involvement of the granule cell population of the cerebellum. Treatments resulting in an early loss of granule cells lead to an abnormal retention of the multiple innervation through adulthood. X-irradiation of neonatal rats (Woodward et al., 1974; Crepel et al., 1976a; Delhaye-Bouchaud et al., 1978; Benoit et al., 1984; Mariani et al., 1990) or viral infection of neonatal ferrets (Benoit et al., 1987) destroys the developing granule cells, and in both conditions monoinnervation is not achieved. Similar strong evidence for a central role of the granule 
cells in the retraction of multiple innervation comes from studies of several cerebellar mutant mice. Staggerer, reeler, and weaver are single-gene mutations whose effects on cerebellar development have been analyzed extensively, both morphologically and physiologically. An important feature shared by these mutants is that the granule cell population is considerably reduced in size, because of the massive death of postmitotic, premigratory granule cells (weaver; Rezai and Yoon, 1972; Rakic and Sidman, 1973; Sotelo and Changeux, 1974b; Goldowitz and Mullen, 1982), target-related cell death (staggerer; Sidman et al., 1962; Yoon, 1972; Sotelo and Changeux, 1974a; Herrup, 1983), or both (reeler; Sidman, 1968; Rakic and Sidman, 1972; Mariani et al., 1977). In addition, abnormalities in Purkinje cell development have also been noted. Intracellular electrophysiological recordings from Purkinje cells of these mutants have revealed a retention of the immature stage of Purkinje cell-inferior olive interaction, namely, polyneuronal innervation (Crepel and Mariani, 1976; Mariani et al., 1977; Crepel et al., 1980; Mariani and Changeux, 1980a). Altogether, data obtained from a variety of granular cell deficient cerebella suggest that the granule cell population somehow promotes the regression of the multiple innervation of the Purkinje cells by climbing fibers.

Lurcher $(L c)$ is an autosomal dominant mutation that causes severe ataxia in heterozygous individuals (Phillips, 1960). In the adult $+/ L c$ mouse the cerebellum is greatly reduced in size due to the loss of all the Purkinje cells and $90 \%$ of the granule cells (Caddy and Biscoe, 1979). The timing of this loss has been investigated by Caddy and Biscoe (1979). By postnatal day 15 (P15), 50\% of the lurcher Purkinje and granule cells have disappeared. By P30, Purkinje cell loss has reached $90 \%$, and by P 90 , no $+/ L c$ Purkinje cells remain. Neurons of the inferior olive (75\%) also degenerate during the first postnatal month (Caddy and Biscoe, 1979). Analyses of $+/ L c \leftrightarrow$ wild-type chimeric mice have revealed much about the site of gene action. Wetts and Herrup (1982a) showed that the Purkinje cells are directly affected by their mutant, $+/ L c$, genotype, whereas mutant granule and olivary cells are only affected secondarily, presumably as a result of the loss of their Purkinje cell target (Wetts and Herrup, 1982b).

These data indicate that, despite a significant amount of Purkinje cell death, $30-50 \%$ of the wild-type number of Purkinje cells are still present in the lurcher cerebellum during the third postnatal week (P14-P21; Caddy and Biscoe, 1979). By this period, polyneuronal innervation of Purkinje cells by climbing fibers has disappeared in normal rodents (Mariani and Changeux, 1980b, 1981a,b; Crepel et al., 1981). The question arises as to the multiple innervation status of the surviving $+/ L c$ Purkinje cells at this age. On the one hand, electron microscopic studies of the mutant cerebellar cortex have demonstrated that, before they die, $+/ L c$ Purkinje cells receive synapses from their main afferents, that is, climbing fibers and parallel fibers (Caddy and Biscoe, 1979; Heckroth et al., 1990; Dumesmil-Bousez and Sotelo, 1992). This suggests that the multiple innervation may regress normally for the mutant cells. On the other hand, the climbing fiber synapses on Purkinje cells remain perisomatic and do not extend up the primary dendritic shaft (Heckroth et al., 1990) as they do in normal mice (Ramon y Cajal, 1911; Larramendi, 1969). This hints at a developmental block in the climbing fiber-Purkinje cell interaction, but in and of itself, the abnormal location should not compromise the synapse elimination process (Mariani, 1983; Sotelo, 1990). Another neurological mutant, hyperspiny $(h p c)$, also bearing perisomatic climb- ing fiber synapses, undergoes a normal process of elimination of supernumerary climbing fiber synapses (Guenet et al., 1983).

Anatomical methods alone are not adequate to determine whether or not Purkinje cells are multiply innervated. We have conducted, therefore, a physiological characterization of the inferior olive-Purkinje cell synaptic relationship in 2-3-week-old lurcher mutants. We have found that the majority of the $+/ L c$ Purkinje cells retain their multiple innervation by climbing fibers up to $\mathrm{P} 20$. The finding raised the additional question of whether the retention of multiple innervation is due to (1) a direct effect of the gene on the Purkinje cell target that makes it incapable of becoming monoinnervated, (2) a deficiency in the granular or olivary afferents, or (3) some other general environmental insult. To answer this question, we have performed additional physiological experiments in adult lurcher chimeric mice.

\section{Materials and Methods}

Animals. Lurcher mutants were provided by the Pasteur Institute (Paris) and raised in our laboratory; the lurcher mutation is maintained on the C57BL/6 × CBA hybrid strain. Mouse pups were obtained either by intercrossing heterozygotes or by mating wild-type with heterozygote mice. The mutant phenotype was recognizable by postnatal day 14 (P14) based on clinical symptoms (ataxia); the diagnosis was further confirmed by histological analysis of the cerebellum at the end of each experiment. As controls, age- and strain-matched wild-type animals were used.

Chimeras were produced according to standard embryo aggregation techniques (Tarkowski, 1961; Mintz, 1965; Mullen and Whitten, 1971). Heterozygote lurcher embryos were produced by mating C.57BL/6J (+) Lc) with C57BL/6J $(+/+)$; wild-type embryos were produced from the inbred strain $\mathrm{C} 3 \mathrm{H} / \mathrm{HeJ}$. Chimeric embryos were obtained by placing an eight-cell-stage embryo from a heterozygote lurcher mating in contact with an eight-cell-stage embryo from a wild-type inbred mouse mating after removal of the zonae pellucidae with pronase (proteinase $\mathrm{H}$, Sigma). The embryos were cultured overnight, and those that successfully aggregated to form double-sized morulas were transplanted into pseudopregnant host females. The resulting pups were delivered either naturally or by Cesarean section $17 \mathrm{~d}$ later. Successful chimeras were identified on the basis of coat color markers and on the results of progeny testing (see Wetts and Herrup, 1983). The degree of chimerism (percentage wild-type) in the cerebellum was determined by measuring the length of the Purkinje cell layer in a midsagittal section of the chimera. A control chimera, made between two wild-type mice (B6AK $\leftrightarrow \mathrm{C} 3 \mathrm{H}$ ), was used as a standard for wild-type, defined as $100 \%$; a lurcher mutant was used for the $0 \%$ value. The percentage wild-type was defined as the ratio of the corresponding lengths:

$$
\text { (chimera - lurcher)/(wild-type - lurcher) } \times 100 \text {. }
$$

The granule cell : Purkinje cell ratio was estimated graphically from the work of Vogel et al. (1989) in which granule cell number was plotted as a dependent variable against Purkinje cell number for a large range of lurcher chimeras. The ratio of inferior olivary neurons to Purkinje cells was estimated from the unpublished data of cell counts by Zanjani, Delhaye-Bouchaud, and Mariani.

Electrophysiology. Lurcher mutant mice (and wild-type controls) were studied at ages ranging from P14 to P20. The chimeric mice were studied at ages ranging from 5 to 7 months. The experimental protocol was the same for all animals: animals were first anesthetized with a $10 \%$ solution of ethyl carbamate $(1 \mathrm{ml} / 100 \mathrm{gm})$, administered in two consecutive intraperitoneal injections, and then paralyzed with $0.2 \mathrm{ml}$ of gallamine triethiodide (Flaxedil) and artificially respired through a tracheal cannula. The central temperature of the animals was maintained at 36$37^{\circ} \mathrm{C}$ throughout the experiment by warming the animal on a heating pad. The posterior cerebellar vermis was exposed and covered with $4 \%$ agar in $10 \%$ sucrose solution. Concentric bipolar electrodes (Rhodes Medical Instruments) were used to stimulate the climbing fiber afferent pathway at the juxtafastigial region ipsilateral to the recording site (JF stimulation). Intracellular and sometimes extracellular recordings of Purkinje cell activity were performed in the cerebellar vermis with glass microelectrodes filled with $3 \mathrm{M}$ potassium acetate, whose DC resistance ranged between 20 and $60 \mathrm{M} \Omega$. 

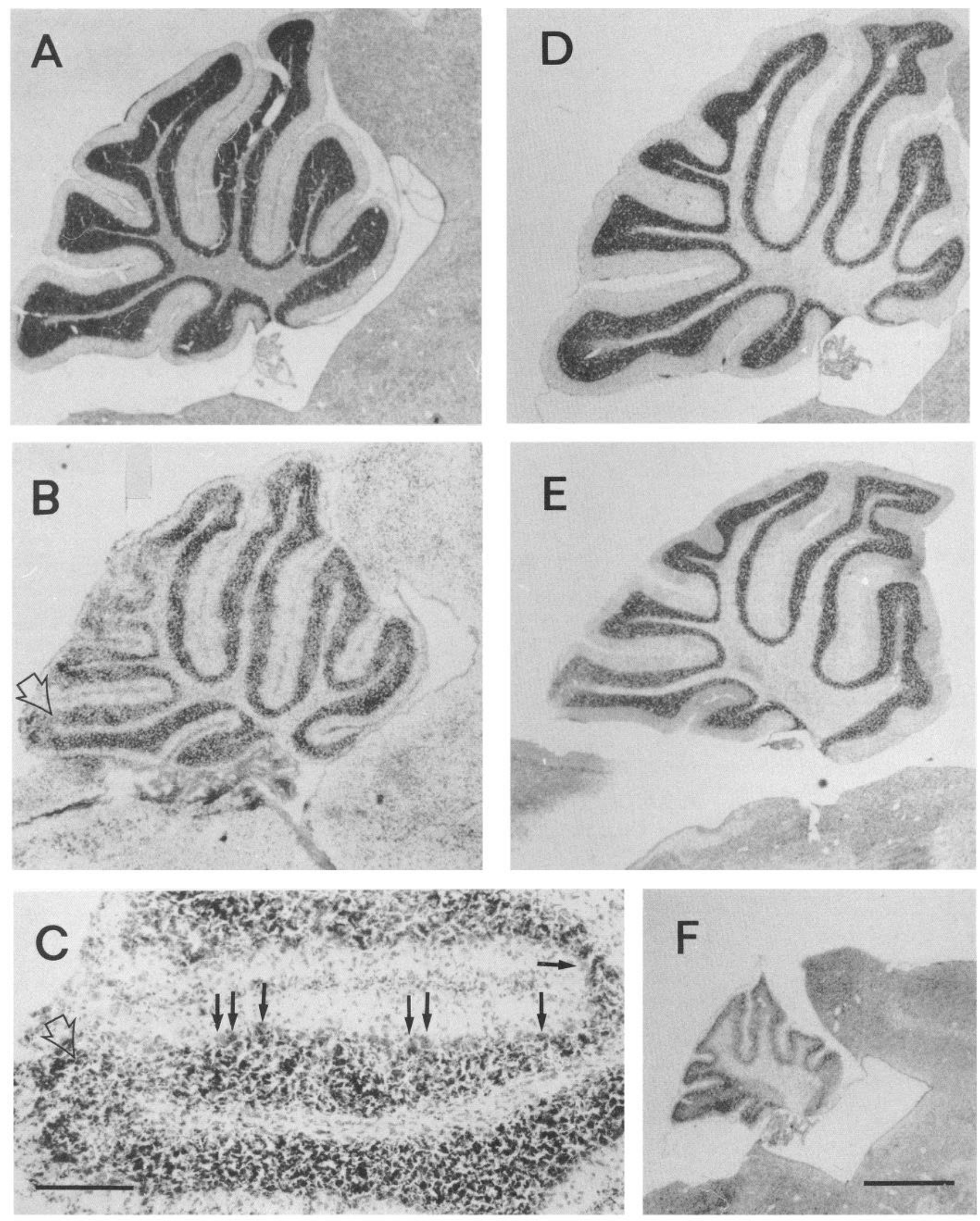

Figure 1. Sagittal sections of the cerebellum stained with thionin. $A$ and $B$, Fifteen-day-old wild-type $(A)$ and lurcher mutant $(B)$; at this age in the mutant $(B)$ Purkinje cells are still common, though less numerous in posterior lobules such as lobule IX (open arrow). $C$, High magnification of lobule IX (area denoted by open arrow in $B$ ). Surviving Purkinje cells are indicated by solid arrows. $D$ - $F$, Adult cerebella of wild-type $(D)$, 50 : 50 wild-type $\leftrightarrow+/ L c$ chimera $(E)$, and lurcher mutant $(F)$. Scale bars: $A, B, D-F, 600 \mu \mathrm{m} ; C, 200 \mu \mathrm{m}$. 
As previously described (Benoit et al., 1987), Purkinje cell impalements were achieved by applying a brief oscillation in the negative capacitance circuit of the amplifier. The recordings were displayed on a storage oscilloscope and stored on a digital videotape recorder (Sony) for further analysis. At the end of the recording session, an iontophoretic injection of fast green was performed at two selected depths along the same track; all recording tracks were parallel to each other allowing Purkinje cells' position to be identified after histological processing.

Histology. After the electrophysiological session, cerebella from the P14-P20 mutant and wild-type mice were rapidly dissected and frozen; $10-15-\mu \mathrm{m}$-thick cryostat sections were cut and stained with thionin (Fig. $1 A-C$ ). The chimeric mice were transcardially perfused with ice-cold $4 \%$ paraformaldehyde in $0.1 \mathrm{M}$ phosphate buffer, $\mathrm{pH} 7.4$; the brains were postfixed in the same fixative for $4-6 \mathrm{hr}$ at $4^{\circ} \mathrm{C}$. The cerebella were embedded in wax, cut in sagittal 10 - $\mu \mathrm{m}$-thick sections, and stained with thionin (Fig. $1 D-F$ ).

\section{Results}

\section{The developing lurcher mutant}

We analyzed 41 developing lurcher mutant mice at different ages from P14 to P20. As controls, 22 wild-type mice of the same age were studied (body weight, 6-9 gm for both groups). This period was selected since it is the latest stage in which a sufficient number of Purkinje cells is still found in the mutant cerebellum (Fig. 1C). No obvious differences were found among animals of like genotype in the P14-P16 age group, and so we have pooled our findings. Intracellular recording of $+/ L c$ Purkinje cells proved difficult, probably due to the fragilc statc of the mutant Purkinje cells. Many penetrations did not lead to any cell recording at all, and many other cells were lost soon after impaling. In the P14-P16 age group, we acquired data from $16+/ L c$ cells and 26 wild-type cells. The lower yield of Purkinje cells in lurcher mutants was expected because a significant number of these cells have already degenerated (see Fig. 1C). Taking this deficiency into account, the sampling of cells in lurcher and wild-type animals was comparable.

Intracellular recordings were performed in the anterior vermis (lobules II-VI), where more Purkinje cells are expected to remain at the end of the second postnatal week (Heckroth et al., 1990). EPSPs elicited by climbing fiber activation (CF-EPSP) could be recorded with their typical features: amplitude of several millivolts, multiwaved shape, and low spontaneous frequency for those occurring spontaneously. It was always possible to determine if a cell received one or several climbing fiber terminals by analyzing the amplitude of the spontaneous and evoked CF-EPSP (Crepel et al., 1981; Mariani and Changeux, 1981a,b). A Purkinje cell was considered as innervated by a single climbing fiber collateral when the amplitude of spontaneously occurring CF-EPSP, or those evoked through JF stimulation, were all-or-none in amplitude. On the other hand, if the amplitude was graded in a stepwise manner (two to five steps depending on the cell), each step was considered to be the contribution of an individual climbing fiber. This pattern identified the Purkinje cell as multiply innervated (by several climbing fiber terminals). It should be noted that the number of steps represents at best a minimal estimate of the number of climbing fiber terminals innervating an individual Purkinje cell (Mariani and Changeux, 1981a; Benoit et al., 1987).

Figure 2 shows Purkinje cell responses to JF stimulation that are representative of the records obtained in lurcher mutants. Both the evoked response $\left(A_{l-4}\right)$ and the spontaneous activity $\left(A_{5}, A_{6}\right.$ and $\left.B_{1}, B_{2}\right)$ reveal the presence of several climbing fiberEPSP steps. $A_{1}-A_{6}$ represent a single $+/ L c$ Purkinje cell that received at least four climbing fiber afferents, while $\mathrm{B}_{1}$ and $B_{2}$
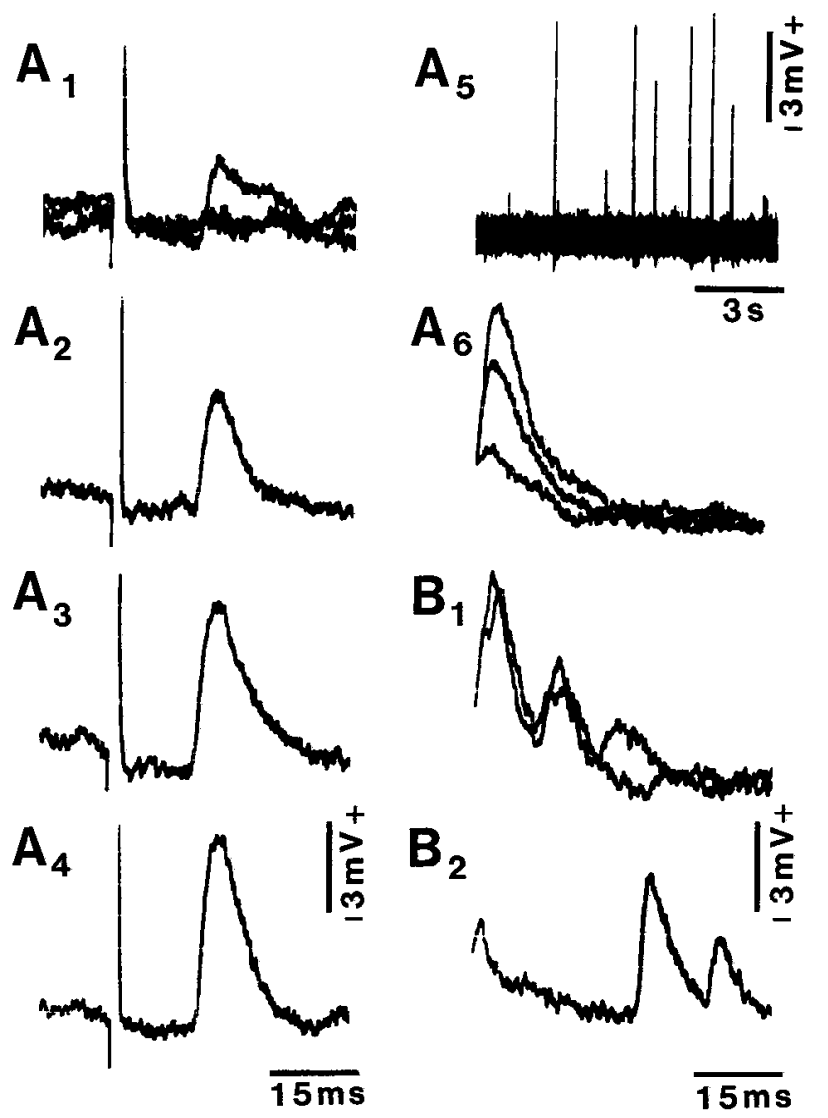

Figure 2. Intracellular recording of climbing fiber-evoked responses from Purkinje cells in P15 lurcher mutant mice. Superimposed sweeps in all traces (except for $A_{2}-A_{4}$ and $B_{2}$ ). $A_{1}-A_{4}$, Climbing fiber-evoked responses obtained by smoothly incrcasing the JF stimulation; four steps are visible, indicating that at least four different climbing fibers innervate this particular Purkinje cell. The same steps are revealed also in the spontaneous EPSP discharge of the same cell $\left(A_{s}\right.$, recorded at lower speed, and $A_{6}$ ). $B_{1}$ and $B_{2}$, Spontaneous discharge of another Purkinje cell, revealing two steps.

show a different Purkinje cell innervated by a minimum of two inferior olivary afferents. Of the 16 Purkinje cells recorded in P14-P16 lurcher mutants, 12 (75\%) were found to have maintained their multiple innervation by climbing fibers as late as P14-P16. In contrast, only $3(10 \%)$ out of 26 Purkinje cells recorded in wild-type mice of the same age were polyinnervated, and these three cells each received only two climbing fibers. The values of the two groups appear statistically different $(p<0.001)$ when applying a $\chi^{2}$ test for two independent samples. The mean number of climbing fibers innervating an individual Purkinje cell in the mutant $(2.06 \pm 0.19, \pm \mathrm{SEM})$ was also significantly higher than in the control $(1.13 \pm 0.08 ; p<0.0001)$. Post facto histological analysis of the cerebella, in particular the lack of Purkinje cells (Fig. $1 A-C$ ), confirmed the behavioral diagnosis of the mutant animals.

Although most of the $+/ L c$ Purkinje cells from which we recorded showed clear evidence of multiple innervation, approximately $25 \%$ did not. We wished to determine whether this small monoinnervated fraction was stable with time or whether the $+/ L c$ Purkinje cells were simply delayed in their maturation. To this end, we attempted Purkinje cell recordings from lurcher mutants at P18-P20. By this age, the difficulties in recording intracellularly from Purkinje cells are severely compounded. The cells are difficult to locate, and when they are found, they 
Table 1. Description of the lurcher chimeras from which Purkinje cell recordings were performed

\begin{tabular}{lllllll} 
Animal & \% Wild-type & $\begin{array}{l}\text { No. of PCs } \\
\text { recorded }\end{array}$ & gc:PC ratio & $\begin{array}{l}\text { gc:PC ratio } \\
\text { \% wild-type }\end{array}$ & $\begin{array}{l}\text { IO:PC } \\
\text { ratio }\end{array}$ & $\begin{array}{l}\text { IO:PC } \\
\text { ratio } \\
\text { \% wild-type }\end{array}$ \\
\hline$\chi 643$ & 100 & 3 & 190 & 100 & 0.12 & 100 \\
$\chi 637$ & 80 & 11 & 225 & 120 & 0.13 & 111 \\
$\chi 610$ & 80 & 1 & 225 & 120 & 0.13 & 111 \\
$\chi 599$ & 60 & 2 & 283 & 150 & 0.15 & 129 \\
$\chi 603$ & 60 & 6 & 283 & 150 & 0.15 & 129 \\
$\chi 638$ & 40 & 9 & 338 & 180 & 0.20 & 165 \\
$\chi 642$ & 40 & 11 & 338 & 180 & 0.20 & 165 \\
$\chi 644$ & 20 & 11 & 429 & 230 & 0.32 & 275 \\
$\chi 602$ & ND & 4 & ND & ND & ND & ND
\end{tabular}

PC, Purkinje cell; gc, granule cell; IO, inferior olive cell. As the percentage of wild-type cell contribution to the chimera decreases from $100 \%$ to $20 \%$, the ratio of granule to Purkinje cells rises. In a $20 \%$ wild-type chimera, this value is $230 \%$ of that found in a nonchimeric, wild-type mouse. Similarly, in the same chimera, the ratio of inferior olive to Purkinje cells reaches $275 \%$ of the value found in wild type. ND, Not determined, but proven to be genetically $+/ L c$ by progeny testing. Based on coat color markers (a crude predictor of brain genotype ratios), $\chi 602$ was estimated to be $10-20 \%$ wild type.

${ }^{a}$ Estimated by measurement of the length of the Purkinje cell layer in a midsagittal section (see Materials and Methods)

rarely survive impalement with microelectrodes. While these problems are undoubtedly due to the fragile health of the $+/ L c$ Purkinje cells, soon destined to die, we were able to obtain usable recordings from four Purkinje cells in $13+/ L c$ animals. Three of these four were multiply innervated, while one was monoinnervated. Though not a statistically significant sample, these data are reasonable evidence that the multiple innervation of $+/ L c$ Purkinje cells is not transient. We did comparable recordings in age-matched control animals. All $28+/+$ Purkinje cells that we impaled were innervated by a single climbing fiber afferent. Thus, the small complement of multiply innervated
A

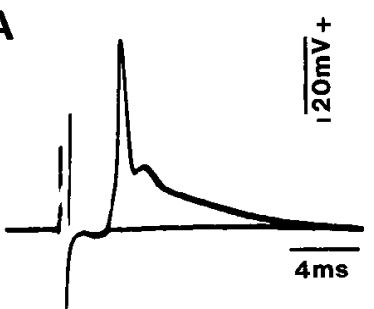

$B_{2}$

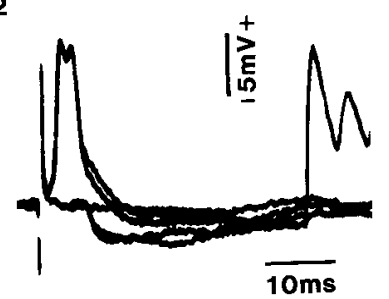

$B_{1}$

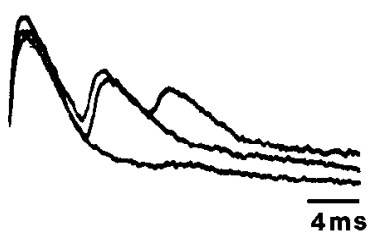

C

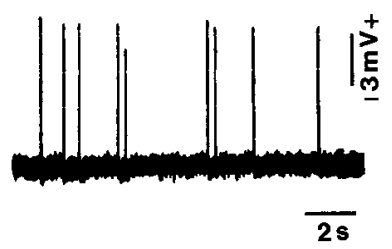

Figure 3. Intracellular recording of climbing fiber-evoked responses from Purkinje cells in lurcher chimera: superimposed sweeps in all traces except $C$. $A-C$ are from three distinct cells. $A$, Climbing fiber full spike, evoked by JF stimulation, exhibiting a clear all-or-none response. $B_{l}$, Spontaneous EPSPs showing the typical all-or-none multiwaved shape. Each sweep triggered by the rising edge of the response. $B_{2}$, Synaptic potentials evoked by JF stimulation. An IPSP was first elicited, and as the intensity of the stimulation was gradually increased, a typical allor-none CF-EPSP was evoked. A spontaneous CF-EPSP also appeared on one of the sweeps. $C$, Spontaneous discharge recorded from another cell at low speed to show the constancy of the EPSPs' amplitude. cells in $+/+$ animals at P14-P16 was indeed a transient population.

In sum, our findings indicate that most Purkinje cells in the $+/ L c$ mouse retain their multiple innervation by climbing fibers. Two possible explanations of this result can be advanced. Either the environment, including the two major afferent systems, is disrupted, or the Purkinje cell itself is intrinsically incapable of becoming monoinnervated. These possibilities can be distinguished through the use of lurcher chimeric mice.

\section{The chimeras: description of the chimeric cerebella}

The introduction of chimeric mice (Tarkowski, 1961; Mintz, 1962, 1965; Mullen, 1977), obtained by the aggregation of one mutant and one wild-type embryo, has significantly extended the usefulness of mutant mice for studies of cerebellar development. In this experimental model, the cells of the two genotypes in cerebellum form a fine-grained mosaic. An important feature of these animals is that the proportion of mutant cells can vary from $0 \%$ (in which case the animal's phenotype is wildtype; Fig. $1 D$ ) to $100 \%$ (in which case the phenotype is lurcher; Fig. $1 F$ ). Figure $1 E$ represents an intermediate case where $50 \%$ of the cells are $+/ L c$; despite this loss of both granule and Purkinje cells, the lobules are easily recognizable and the characteristic organization of the cerebellar layers appears normal. In the lurcher chimeras, as described by Wetts and Herrup (1982a,b, 1983), all $+/ L c$ Purkinje cells degenerate whereas genetically $+/ L c$ granule and olivary cells are not preprogrammed to die. As a result, the adult chimeric cerebellum contains only genetically wild-type Purkinje cells in an environment that ranges from wild-type to nearly mutant in composition. Indeed, while all three cell types in the cerebellar circuit suffer some cell loss, the ratio of granule cells and inferior olive neurons to individual Purkinje cells is higher than normal (Vogel et al., 1989).

\section{The chimeras: electrophysiological results}

Recordings were obtained from Purkinje cells in a total of nine lurcher chimeric animals, and 58 cells were retained for analysis. The number of Purkinje cells analyzed per individual animal is shown in Table 1. In some of the Purkinje cells tested, a full 
spike typical of the climbing fiber response (Eccles et al., 1966) was recorded before deterioration of the cell (Fig. $3 A$ ). In most Purkinje cells, the degradation of the cell leads rapidly to the suppression of the spike potentials. Only the underlying CFEPSPs were recorded for several minutes, while the resting potential remained stable from -30 to $-50 \mathrm{mV}$ (according to the impalement). In some cells, the initial part of the full spike did not rise abruptly from the baseline as it does in normal animals; rather, it developed after the onset of a visible EPSP, as is often observed in the staggerer mutant (Mariani and Changeux, 1980a) and in developing animals (Mariani and Changeux, 1981a).

All CF-EPSPs recorded in these chimeras showed features typical of those recorded from Purkinje cells in normal mice (Mariani, 1982) (Fig. $3 B_{1}, B_{2}, C$ ). Sometimes an IPSP was recorded (Fig. $3 B_{2}$ ), presumably due to the activation of cerebellar inhibitory interneurons by the mossy fiber pathway after JF stimulation (Eccles et al., 1967). The analysis of both spontaneous (Fig. $3 B_{1}, C$ ) and evoked (Fig. $3 B_{2}$ ) climbing fiber responses clearly showed that all Purkinje cells recorded in our lurcher chimeras received their olivary input from a single climbing fiber terminal. This conclusion takes on special significance in chimeras 644 and 602 . In these animals, only $20 \%$ of the wild-type number of Purkinje cells and $45 \%$ of the wildtype number of granule cells survived. Nonetheless, all 15 Purkinje cells from which we recorded were monoinnervated.

In some cases, extracellular unitary activity from Purkinjc cells was recorded prior to impalement. Purkinje cells in the chimera exhibit the same types of responses evoked by JF stimulation (Fig. 4) as do those found in wild-type mice (Crepel and Mariani, 1975) and in other mammals (Eccles et al., 1967). Simple spikes (Fig. $4 A_{1}$ ), evoked by the activation of the parallel fibers, were observed as were complex responses with inactivation of secondary spikes (Fig. $4 A_{2}, A_{3}$ ). The latter responses were due to climbing fiber activation. Finally the typical antidromic response caused by the direct activation of Purkinje cell axons in the cerebellar white matter was observed (Fig. $4 A_{3}$ ).

\section{Discussion}

The results presented here indicate that, in the lurcher mutant, the Purkinje cells retain the multiple innervation by climbing fibers usually associated with younger, more immature cells. Intracellular recordings of CF-EPSP, either evoked by JF stimulation or spontaneous, were obtained to provide a sensitive measure of the degree of multiple innervation (Mariani and Changeux, 1981a; Benoit et al., 1987). In the P14-P16 lurcher mutant, $75 \%$ of the Purkinje cells that we examined were innervated by more than one climbing fiber. In contrast, $90 \%$ of the Purkinje cells we recorded in wild-type mice were monoinnervated by this age. By P18-P20, lurcher Purkinje cells were very difficult to impale. Yet of those that could be found, most (three of four) were still multiply innervated. By contrast, 100\% of the Purkinje cells in age-matched wild-type mice were monoinnervated by this age (as were all P15 rat Purkinje cells we have examined previously; Crepel et al., 1981; Mariani and Changeux, 1981a).

Our previous studies, as well as those of others, have heavily emphasized the role of the granule cell parallel fibers in the elimination of supernumerary climbing fiber afferents. This emphasis was occasioned by the observation that multiple innervation of Purkinje cells is abnormally retained in several model systems where granule cell afferents are removed early in development. These include X-irradiated rats (Woodward et al.,
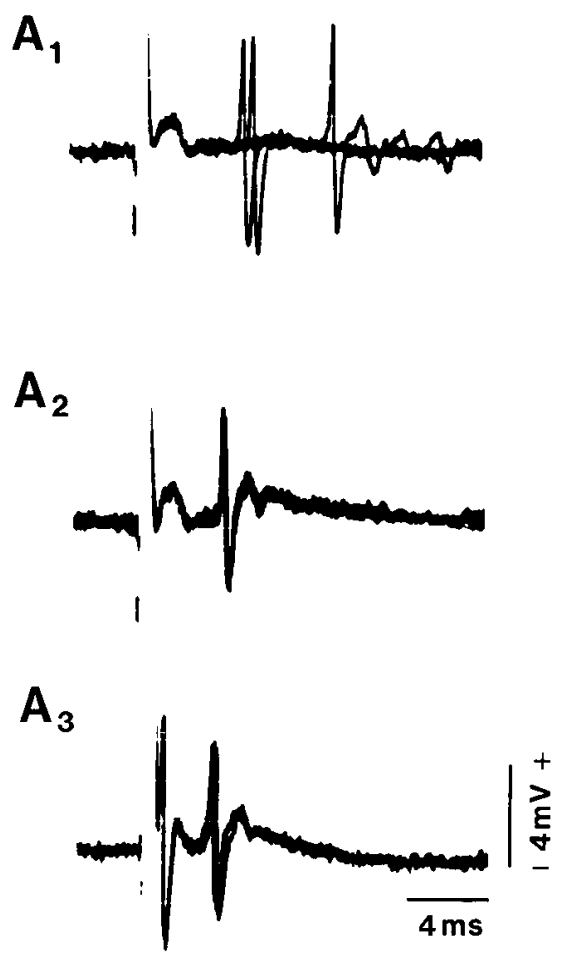

Figure 4. Extracellular recording of Purkinje cell activity evoked by JF stimulation in a lurcher chimera: superimposed sweeps in all traces. $A,-A_{3}$ are from the same cell. A stimulus just above threshold evoked a single spike response followed by a spontaneous complex spike $\left(A_{i}\right)$. When the intensity of the JF stimulation was increased, a complex spike response was recorded $\left(A_{2}\right)$, preceded by a short-latency antidromic spike when the stimulus was further increased $\left(A_{3}\right)$.

1974; Crepel et al., 1976a; Delhaye-Bouchaud et al., 1978; Benoit et al., 1984; Mariani et al., 1990), virally infected ferrets (Benoit et al., 1987), and several mutant mice (Crepel and Mariani, 1976; Mariani et al., 1977; Crepel et al., 1980; Mariani and Changeux, 1980a; Mariani, 1982).

At first, our observations on lurcher animals would seem to be additional evidence in support of the hypothesis that something associated with the early arrival of healthy granule cell afferents is a stimulus that triggers the establishment of monoinnervation. Granule cell death (as measured by the appearance of pyknotic nuclei) is seen in the $+/ L c$ cerebellum as early as P4 (Swisher and Wilson, 1977). Also, as in other mutants with early postnatal granule cell death (weaver, reeler, and staggerer; Crepel and Mariani, 1976; Mariani et al., 1977; Crepel et al., 1980; Mariani and Changeux, 1980), multiple innervation is retained in the lurcher. On the other hand, the ages at which the majority of granule cell death occurs in $+/ L c$ mice are relatively advanced compared to the other animals. Studies in rat have shown that destruction of granule cells by $\mathrm{X}$-ray treatments is effective in blocking the development of monoinnervation only if it is performed before P8 (Delhaye-Bouchaud et al., 1978; Y. Bailly, N. Delhaye-Bouchaud, and J. Mariani, unpublished observations). In the $+/ L c$ mutant, however, nearly $80 \%$ of the wild-type number of granule cells are still present at this age (Caddy and Biscoe, 1979). Further, recent quantitative studies (Dumesnil-Bousez and Sotelo, 1992) reveal that the number of synapses between parallel fibers and Purkinje cell dendrites is the same in young $+/ L c$ and in wild-type cerebellum. If the early granule cell death is not sufficient to remove the monoin- 
nervation stimulus in $+/ L c$ cerebellum, then why does Purkinje cell multiple innervation persist?

Our findings from Purkinje cell recordings in the $+/ L c \leftrightarrow$ $+/+$ chimeras provide an alternative explanation for the $+/ L c$ abnormality. In the lurcher chimeric cerebellum, all $+/ L c$ Purkinje cells die during development due to the direct effect of the mutation; only wild-type Purkinje cells survive into adulthood (Wctts and Herrup, 1983). In our ninc chimcras, with varying percentages of lurcher contribution to the chimera, all of the 58 recorded $(+/+)$ Purkinje cells were innervated by a single climbing fiber. This is in direct contrast to the polyinnervation seen in $+/ L c$ mutants. Even in the environment of chimeras that are predominantly lurcher ( $>80 \%$ ), genetically wild-type Purkinje cells are thus able to achieve the monoinnervation characteristic of normal olivocerebellar development. Although the chimeras were adults at recording, this difference is unlikely to explain the distinct innervation statuses of these two types of Purkinje cells. It has previously been demonstrated that, if synapse elimination is prevented in early postnatal life, multiple innervation is stable throughout life (Benoit et al., 1984). The implication is that the retention of extra climbing fibers in the $+/ L c$ Purkinje cells is not due to a defect in the cellular environment (e.g., excessive granule cell death), but rather to an intrinsic failure of the Purkinje cell itself to undergo a normal process of elimination of climbing fiber synapses.

The contrast between the behavior of the $+/ L \mathcal{C}$ and the $+/+$ Purkinje cells in nearly the same environment suggests a modification of the theory concerning the regression of the multiple innervation. The arrival of the parallel fibers may indeed trigger the withdrawal of supernumerary climbing fiber synapses, but the Purkinje cell must contribute to the process as an active participant. Thus, one plausible explanation for our findings is that the $+/ L c$ Purkinje cells are either developmentally blocked or intrinsically incompetent to respond to normal granule cell input. We suggest that, while the parallel fiber stimulus to withdraw supernumerary climbing fibers is adequate in the mutant, the $+/ L c$ Purkinje cells cannot respond to this stimulus.

The $+/+$ Purkinje cells in the chimera are developmentally competent, and they mature to the stage of monoinnervation. This competence is all the more remarkable since (although they start off with a normal shape; Soha and Herrup, 1991; J. Soha and $\mathrm{K}$. Herrup, unpublished observations), by adulthood, the dendrite of the $+/+$ Purkinje cell has become atrophic, poorly branched, and oddly shaped (Caddy and Herrup, 1990, 1991). Even with these abnormalities, ultrastructural studies have shown that the Purkinje cells receive qualitatively normal synaptic contacts from both climbing and parallel fibers (Caddy and Herrup, 1991), in good agreement with our recordings of both complex and simple spikes from these cells.

The expansion of the theory brought about by our findings in no way changes the interpretation of the $\mathrm{X}$-irradiation or virus infection experiments. In these situations, the early loss of the granule cell input removes the trigger for monoinnervation and multiple innervation persists. On the other hand, it calls into question the cause of the observed multiple innervation status of some of the neurological mutants examined to date. The results in the reeler mouse (in which ectopic Purkinje cells that never receive granule cell input remain multiply innervated while normally positioned Purkinje cells develop monoinnervation; Mariani et al., 1977) can be interpreted as a difference in parallel fiber innervation. However, the retention of multiple innervation in the staggerer and weaver mouse may not be solely caused by the existence of massive granule cell death during development and the lack of synapses between parallel fibers and Purkinje cells. Instead, since the staggerer Purkinje cell is also believed to be developmentally blocked at early postnatal ages (Sidman, 1968; Herrup and Mullen, 1979, 1981; Messer et al., 1990), the multiple innervation in this mutant might be due either to the granule cell deficiency or to the Purkinje cell incompetence. Thus, in $s g / s g$, as in $+/ L c$, the persistence of multiple innervation may involve an abnormality of the Purkinje cell itself. In weaver, Smeyne and Goldowitz (1990) have argued that some of the Purkinje cell phenotypes represent direct effects of the mutant gene. Perhaps these are extended to include a block in the ability of the cell to develop monoinnervation.

Our findings are also relevant to the study by Panzini and Herrup (1987), who found that there was an increase in the ratio of inferior olive to Purkinje cell neurons in the lurcher chimera over that found in wild type. While several possible explanations for this increase were suggested, one attractive possibility was that the $+/+$ Purkinje cells remained multiply innervated in the chimeras. This situation might provide the inferior olive population with an effectively larger postsynaptic target. The finding of monoinnervation for all chimeric $+/+$ Purkinje cells eliminates this alternative. Indeed, the increased ratio of olive to Purkinje cell suggests that even in the presence of increased "demand" for synaptic space (occasioned by the increased olive : Purkinje cell ratio), the development of monoinnervation is not blocked.

This study therefore provides new insight into the mechanisms involved in the process of elimination of climbing fiberPurkinje cell supernumerary synapses during development. In particular, our results suggest that an interplay of factors is necessary for the establishment of monoinnervation: the granule cell input is effective in its role only if the target Purkinje cells have reached a stage of differentiation sufficient to allow them to develop the cascade of intracellular events that respond to this input and culminate in the stabilization of a single climbing fiber.

\section{References}

Benoit P, Delhaye-Bouchaud N, Changeux JP, Mariani J (1984) Stability of multiple innervation of Purkinje cells by climbing fibers in the agranular cerebellum of old rats X-irradiated at birth. Brain Res 14:310-313.

Benoit P, Mariani J, Delhaye-Bouchaud N, Chappuis G (1987) Evidence for a multiple innervation of cerebellar Purkinje cells by climbing fibers in adult ferrets infected at birth by a mink enteritis virus. Dev Brain Res 34:51-57.

Caddy KWT, Biscoe TJ (1979) Structural and quantitative studies on the normal $\mathrm{C} 3 \mathrm{H}$ and lurcher mutant mouse. Philos Trans R Soc Lond [Biol] 287:167-201.

Caddy KWT, Herrup K (1990) Studies of the dendritic tree of wildtype cerebellar Purkinje cells in lurcher chimeric mice. J Comp Neurol 297:121-131.

Caddy KWT, Herrup K (1991) The fine structure of the Purkinje cell and its afferents in lurcher chimeric mice. J Comp Neurol 306:1-14.

Cowan WM, Fawcett JW, O'Lcary DDM, Stanficld BB (1984) Regressive events in neurogenesis. Science 225:1258-1265.

Crepel F, Mariani J (1975) Anatomical, physiological and biochemical studies of the cerebellum from mutant mice. I. Electrophysiological analysis of cerebellar cortical neurons in the staggerer mouse. Brain Res 98:135-147.

Crepel F, Mariani J (1976) Multiple innervation of Purkinje cells by climbing fibres in the cerebellum of the weaver mutant mouse. $J$ Neurobiol 7:579-582.

Crepel F, Delhaye-Bouchaud N, Legrand J (1976a) Electrophysiological analysis of the circuitry and of the corticonuclear relationships 
in the agranular cerebellum of irradiated rats. Arch Ital Biol 114:4974

Crepel F, Mariani J, Delhaye-Bouchaud N (1976b) Evidence for a multiple innervation of Purkinje cells by climbing fibres in the immature rat cerebellum. J Neurobiol 7:567-578.

Crepel F, Delhaye-Bouchaud N, Guastavino JM, Sampaio I (1980) Multiple innervation of cerebellar Purkinje cells by climbing fibers in staggerer mutant mouse. Nature 283:483-484.

Crepel F, Delhaye-Bouchaud N, Dupont J (1981) Fate of the multiplc innervation of cerebellar Purkinje cells by climbing fibers in immature control, X-irradiated and hypothyroid rats. Dev Brain Res 1:59-71.

Delhaye-Bouchaud N, Crepel F, Mariani J (1975) Mise en évidence d'une multi-innervation temporaire des cellules de Purkinje du cervelet par les fibres grimpantes au cours du développement chez le rat. C R Acad Sci Ser III Sci Vie 281:909-912.

Delhaye-Bouchaud N, Mory G, Crepel F (1978) Differential role of granule cells in the specification of synapses between climbing fibers and cerebellar Purkinje cells in the rat. Neurosci Lett 9:51-58.

Dumesnil-Bousez N, Sotelo C (1992) Early development of the lurcher cerehellum: Purkinje cell alterations and impairment of synaptogenesis. $J$ Neurocytol, in press.

Eccles JC, Llinas R, Sasaki K (1966) The excitatory synaptic action of climbing fibers on the Purkinje cells of the ccrebcllum. J Physiol (Lond) 182:268-296.

Eccles JC, Ito M, Szentagothai J (1967) The cerebellum as a neuronal machine. New York: Springer.

Goldowitz D, Mullen RJ (1982) Granule cell as a site of gene action in the weaver mouse cerebellum: evidence from heterozygous mutant chimeras. J Neurosci 2:1474-1485.

Guenet JL, Sotelo C, Mariani J (1983) Hyperspiny Purkinje cell. A new neurological mutation in the mouse. J Hered 74:105-108.

Heckroth JA, Goldowitz D, Eisenman LM (1990) Olivocerebellar fiber maturation in normal and lurcher mutant mice: defective development in lurcher. J Comp Neurol 291:415-430.

Herrup K (1983) Role of staggerer gene in determining cell number in cerebellar cortex. I. Granule cell death is an indirect consequence of staggerer gene action. Dev Brain Res 11:267-274.

Herrup K, Mullen RJ (1979) Staggerer chimeras: intrinsic nature of Purkinje cell defects and implications for normal cerebellar development. Brain Res 178:443-457.

Herrup K, Mullen RJ (1981) Role of staggerer gene in determining cell number in the cerebellar cortex: a quantitative analysis of staggerer chimeric mice. Dev Brain Res 1:475-485.

Innocenti GM (1981) Transitory structures as substrate for developmental plasticity of the brain. Dev Neurosci 13:305-333.

Jackson H, Parks TN (1982) Functional synapse elimination in the developing avian cochlear nucleus with simultaneous reduction in cochlear nerve axon branching. J Neurosci 2:1736-1743.

Johnson DA, Purves D (1981) Postnatal reduction of neural unit size in the rabbit ciliary ganglion. J Physiol (Lond) 318:143-159.

Larramendi LMH (1969) Analysis of synaptogenesis in the cerebcllum of the mouse. In: Neurobiology of cerebellar evolution and development (Llinas R, ed), pp 803-843. Chicago: American Medical Associalion.

Lichtman JW (1977) The reorganization of synaptic connections in the rat submandibular ganglion during postnatal development. J Physiol (Lond) 273:155-177.

Lichtman JW, Purves D (1980) The elimination of redundant preganglionic cells in early postnatal life. J Physiol (Lond) 301:213-228.

Mariani J (1982) Extent of multiple innervation of Purkinje cells by climbing fibers in the olivo-cerebellar system of weaver, reeler and staggerer mutant mice. J Neurobiol 13:119-126.

Mariani J (1983) Elimination of synapses during the development of the central nervous system. Prog Brain Res 58:383-392.

Mariani J, Changeux JP (1980a) Multiple innervation of Purkinjc cclls by climbing fibers in the cerebellum of the adult staggerer mutant mouse. J Neurobiol 11:41-50.

Mariani J, Changeux JP (1980b) Etude par enregistrements intracellulaires de l'innervation multiple des cellules de Purkinje par les fibres grimpantes dans le cervelet du rat en développement. C R Acad Sci [D] (Paris) 291:97-100.

Mariani J, Changeux JP (1981a) Ontogenesis of olivocerebellar relationships. I. Studies by intracellular recordings of the multiple innervation of Purkinje cells by climbing fibers in the developing rat cerebellum. J Neurosci 1:696-702.
Mariani J, Changeux JP (1981b) Ontogenesis of olivo-cerebellar relationship. II. Spontaneous activity of inferior olivary neurons and climbing fiber-mediated activity of cerebellar Purkinje cells in developing rats. J Neurosci 1:703-709.

Mariani J, Delhaye-Bouchaud N (1987) Elimination of functional synapses during the development of the nervous system. News Physiol Sci 1:93-97.

Mariani J, Crepel F, Mikoshiba K, Changeux JP, Sotelo C (1977) Anatomical, physiological and biochemical studics of the ccrebellum from reeler mutant mouse. Philos Trans R Soc Lond [Biol] 281:128.

Mariani J, Benoit P, Hoang MD, Thompson M, Delhaye-Bouchaud N (1990) Extent of multiple innervation of cerebellar Purkinje cells by climbing fibers in adult $\mathrm{X}$-irradiated rats. Comparison of different schedules of irradiation during the first postnatal week. Dev Brain Res 57:63-70.

Messer A, Plummer-Siegard J, Eisenberg B (1990) Staggerer mutant mouse Purkinje cells do not contain detectable calmodulin mRNA. J Neurochem 55:293-302.

Mintz B (1962) Formation of genotypically mosaic mouse embryos. Am Zool 2:432.

Mintz B (1965) Genetic mosaicism in adult mice of quadriparental lineage. Science 148:1232-1233.

Mullen RJ (1977) Site of $p c d$ gene action and Purkinje cell mosaicism in cerebella of chimeric mice. Nature 270:245-247.

Mullen RJ, Whitten WK (1971) Relationship of genotype and degree of chimerism in coat color to sex ratios and gametogenesis in chimeric mice. J Exp Zool 178:165-176.

Panzini L, Herrup K (1987) Cell death in the inferior olive as a function of cerebellar Purkinje cell number: a quantitative study in lurcher chimeric mice. Soc Neurosci Abstr 13:239.9.

Phillips RJS (1960) "Lurcher," a new gene in linkage group XI of the house mouse. J Genet 57:35-42.

Purves D (1977) The formation and maintenance of synaptic connections. In: Function and formation of neural systems (Stent GS, ed), pp 21-49. Berlin: Dahlem Konferenzen.

Purves D, Lichtman JW (1980) The formation and maintenance of synaptic connections in autonomic ganglia. Physiol Rev 58:821-862.

Rakic P, Sidman RL (1972) Synaptic organization of displaced and disoriented cerebellar cortical neurons in reeler mice. J Neuropathol Exp Neurol 31:192.

Rakic P, Sidman RL (1973) Organization of cerebellar cortex secondary to deficit of granule cells in "Weaver" mutant mice. J Comp Neurol 152:133-162.

Ramon y Cajal (1911) Histologie du systeme nerveux de l'homme et des vertebres. Paris: Maloine.

Redfern PA (1970) Neuromuscular transmission in newborn rats. J Physiol (Lond) 209:701-709.

Rezai Z, Yoon CH (1972) Abnormal rate of granule cell migration in the cerebellum of "weaver" mutant mice. Exp Biol 29:17-26.

Sidman RL (1968) Development of interneuronal connection in brains of mutant mice. In: Physiological and biochemical aspects of nervous integration (Carlson FD, ed), pp 163-193. Englewood Cliffs, NJ: Prenlice Hall.

Sidman RL, Lane PW, Dickie MM (1962) Staggerer: a new mutation in the mouse affecting the cerebellum. Science 137:610-612.

Smeyne R, Goldowitz D (1990) Purkinje cell loss is due to a direct action of the weaver gene in Purkinje cells: evidence from chimeric mice. Dev Brain Res 52:211-218.

Soha J, Herrup K (1991) A developmental Golgi study of Purkinje cell dendritic morphology in lurcher chimeric mice. Soc Neurosci Abstr 17:36.

Sotelo C (1990) Cerebellar synaptogenesis: what we can learn from mutant mice. J Exp Biol 153:225-249.

Sotelo C, Changeux JP (1974a) Transsynaptic degeneration "cn cascade" in cerebellar cortex of staggerer mutant mice. Brain Res 67: 519-526.

Solelo C, Changeux JP (1974b) Bergmann fibers and granule cell migration in the cerebellum of homozygous weaver mutant mice. Brain Res 77:484-491

Swisher DA, Wilson DB (1977) Cerebellar histogenesis in the lurcher (Lc) mutant mouse. J Comp Neurol 173:205-218.

Tarkowski AK (1961) Mouse chimeras developed from fused eggs. Nature 190:857-860.

Vogel MW, Sunter K, Herrup K (1989) Numerical matching between 
granule and Purkinje cells in lurcher chimeric mice: a hypothesis for the trophic rescue of granule cells from target-related cell death. J Neurosci 9:3454-3462.

Wetts R, Herrup K (1982a) Interaction of granule, Purkinje and olivary neurons in lurcher chimeric mice. I. Qualitative studies. J Embryol Exp Morphol 68:87-98.

Wetts R, Herrup K (1982b) Interaction of granule, Purkinje and inferior olivary neurons in lurcher chimeric mice. II. Granule cell death. Brain Res 250:358-363.
Wetts R, Herrup K (1983) Direct correlation between Purkinje and granule cell number in the cerebella of lurcher chimeras and wildtype mice. Dev Brain Res 10:41-47.

Woodward DJ, Hoffer BJ, Altman J (1974) Physiological and pharmacological properties of Purkinje cells in rat cerebellum degranulated by postnatal X-irradiation. J Neurobiol 5:283-304.

Yoon CH (1972) Developmental mechanism for changes in cerebellum of staggerer mouse, a neurological mutant of genetic origin. Neurology 22:743-754. 